\title{
Is Laying a Large Egg Expensive? Female-Biased Cost of First Reproduction in a Petrel
}

Author(s): Ana Sanz-Aguilar, Eduardo Mínguez, and Daniel Oro

Source: The Auk, 129(3):510-516. 2012.

Published By: The American Ornithologists' Union

URL: http://www.bioone.org/doi/full/10.1525/auk.2012.12011

BioOne (www.bioone.org) is a nonprofit, online aggregation of core research in the biological, ecological, and environmental sciences. BioOne provides a sustainable online platform for over 170 journals and books published by nonprofit societies, associations, museums, institutions, and presses.

Your use of this PDF, the BioOne Web site, and all posted and associated content indicates your acceptance of BioOne's Terms of Use, available at www.bioone.org/page/terms_of_use.

Usage of BioOne content is strictly limited to personal, educational, and non-commercial use. Commercial inquiries or rights and permissions requests should be directed to the individual publisher as copyright holder. 


\title{
IS LAYING A LARGE EGG EXPENSIVE? FEMALE-BIASED COST OF FIRST REPRODUCTION IN A PETREL
}

\author{
Ana Sanz-Aguilar, ${ }^{1,4}$ Eduardo Mínguez, ${ }^{2}$ and Daniel Oro ${ }^{3}$ \\ ${ }^{1}$ Biostatistics and Biology of Populations Group, Centre d'Ecologie Fonctionelle et Evolutive (CEFE-CNRS) UMR 5175, 1919 Route de Mende, \\ Montpellier, F-34293, France; \\ ${ }^{2}$ Parque Natural Serra Gelada y su entorno litoral (Generalitat Valenciana), Paseo de la Carretera 34, Benidorm, Alicante, 03501, Spain; and \\ ${ }^{3}$ Population Ecology Group, Instituto Mediterráneo de Estudios Avanzados, Consejo Superior de Investigaciones Cientificas and Universidad de las \\ Islas Baleares, Miquel Marqués 21, Esporles, Mallorca, 07190, Spain
}

\begin{abstract}
Differential reproductive investment between sexes can lead to asymmetric costs of reproduction in birds. Long-lived procellariiform seabirds are single-egg layers with little sexual dimorphism and similar parental investment in incubation and chick rearing. However, sex-specific tasks exist at the beginning of the breeding season, including egg production by females (no courtship feeding by males in this group of species) and nest and mate guarding by males. Costs of reproduction could be evident during critical periods such as the first breeding attempt, because of inexperience in reproductive tasks or a higher proportion of low-quality individuals in young age classes, or both. Little is known about sex-specific costs of reproduction in monomorphic species, in which we expect costs to be similar. We investigated the effects of first reproduction on the subsequent survival of male and female European Storm-Petrels (Hydrobates pelagicus) and found that female survival (0.72; 95\% confidence interval [CI]: 0.60-0.82) was lower than that of males $(0.85$; 95\% CI: 0.76-0.89) after first reproduction. However, these differences were not observed in subsequent breeding attempts by experienced females $(0.89$; $95 \%$ CI: $0.86-0.91)$ and males $(0.88$; $95 \%$ CI: $0.86-0.91)$, probably because of an experience-related improvement in foraging efficiency, reproductive tasks, or predator avoidance. The effort invested by inexperienced females in the production of a large egg $(\leq 25 \%$ of adult body mass) may explain our observed differences in survival. Received 25 January 2012, accepted 14 May 2012.
\end{abstract}

Key words: breeding biology, egg size, European Storm-Petrel, first reproduction, Hydrobates pelagicus, mark-recapture statistics, reproductive effort, survival.

\section{¿Es Costoso Poner un Huevo Grande? Coste de la Primera Reproducción de las Hembras de un Petrel}

RESUMEN.-La inversión reproductiva diferencial entre sexos puede llevar a costes asimétricos de la reproducción en las aves. Las aves procelariformes son de vida larga y ponen un solo huevo, tienen poco dimorfismo sexual y presentan patrones similares de inversión parental en la incubación y la cría de los polluelos. Sin embargo, existen tareas específicas de cada sexo al principio de la temporada reproductiva, incluyendo la producción de huevos por parte de las hembras (no hay alimentación de cortejo por parte de los machos en este grupo de especies), y la defensa del nido y de la pareja por parte de los machos. Los costes de la reproducción podrían ser evidentes durante periodos críticos como el primer intento reproductivo debido a la inexperiencia en las tareas reproductivas y/o a una mayor proporción de individuos de baja calidad en las clases de edad jóvenes. Se sabe poco sobre los costes específicos de la reproducción de cada sexo en especies monomórficas, en las que se espera que los costes sean similares. Investigamos los efectos de la primera reproducción en la supervivencia subsiguiente de machos y hembras de Hydrobates pelagicus, y encontramos que la supervivencia de las hembras (0.72; intervalo de confianza del 95\% [IC]: 0.60-0.82) fue menor que la de los machos (0.85; IC 95\%: 0.76-0.89) después de la primera reproducción. Sin embargo, estas diferencias no fueron observadas en los intentos reproductivos subsiguientes de las hembras experimentadas (0.89; IC 95\%: 0.86-0.91) y de los machos (0.88; IC 95\%: 0.86-0.91), probablemente debido a una mejora relacionada con la experiencia de la eficiencia de forrajeo, las tareas reproductivas,o la evasión de depredadores. El esfuerzo invertido por las hembras no experimentadas en la producción de un huevo grande ( $\leq 25 \%$ de la masa corporal del adulto) podría explicar las diferencias que observamos en la supervivencia.

REPRODUCTION IS A costly process in which high reproductive investment may have implications for future survival, reproductive output, or both (Stearns 1992). Studies that evaluate the costs of reproduction in bird species are usually based on experimental manipulations in which individuals are forced to increase or reduce their current reproductive investment (Reznick 1992, Mínguez 1998, Murphy 2000, Visser and Lessells 2001, de Heij et al. 2006, Navarro and González-Solís 2007). With increased

${ }^{4}$ E-mail: ana.sanzaguilar@cefe.cnrs.fr

The Auk, Vol.129, Number 3, pages 510-516. ISSN 0004-8038, electronic ISSN 1938-4254. (C 2012 by The American Ornithologists' Union. All rights reserved. Please direct all requests for permission to photocopy or reproduce article content through the University of California Press's Rights and Permissions website, http://www.ucpressjournals com/reprintInfo.asp. DOI: 10.1525/auk.2012.12011 
reproductive effort, individuals typically paid fitness costs in reduced survival, reduced breeding probabilities, or both (Murphy 2000, de Heij et al. 2006). However, under natural conditions, it is possible to identify individual factors that influence costs of reproduction, such as age, sex, breeding experience, or intrinsic quality (McNamara and Houston 1996, Tavecchia et al. 2001, Townsend and Anderson 2007, Sanz-Aguilar et al. 2008). In particular, the first breeding attempt has been shown to be a critical period during which individuals may incur particularly high costs of reproduction (Tavecchia et al. 2001, Barbraud and Weimerskirch 2005, Sanz-Aguilar et al. 2008). Costs of first reproduction have been detected among several long-lived birds, such as seabirds, raptors, storks, and waterfowl (Viallefont et al. 1995, Nevoux et al. 2008, Sanz-Aguilar et al. 2008, Hernández-Matías et al. 2011). First-time breeders typically have a lower probability of breeding successfully (Weimerskirch 1990; Nevoux et al. 2007, 2008; Sanz-Aguilar et al. 2008), a lower local survival or return rate than that of experienced breeders (Pyle et al. 1997; Barbraud and Weimerskirch 2005; Nevoux et al. 2007, 2008; Townsend and Anderson 2007; Sanz-Aguilar et al. 2008), and a higher probability of not breeding in the following year (Weimerskirch 1990, Viallefont et al. 1995, Cam and Monnat 2000, Barbraud and Weimerskirch 2005).

Among birds, reproduction involves several potentially costly processes: mate acquisition, territorial defense, egg production, incubation, and chick rearing (Ramírez et al. 2010). Feeding and caring for young has been identified as the costliest of the reproductive phases (Lack 1947, Drent and Daan 1980). However, egg production and incubation are also energetically expensive activities that require additional nutrient acquisition and mobilization of fat reserves (Monaghan and Nager 1997, Nager et al. 2001, Visser and Lessells 2001, de Heij et al. 2006). Although the physiological mechanisms that translate current reproductive effort into future survival or reproduction costs are poorly understood (Zera and Harshman 2001, Harshman and Zera 2007), both resource-allocation tradeoffs (e.g., protein depletion that impairs flight-muscle function, immunosuppression) and pleiotropic effects of reproductive hormones (e.g., anemia) have been proposed as mechanisms that drive future reproductive costs (Hanssen et al. 2005, Williams 2005, Nager 2006, Wagner et al. 2008).

In birds, $90 \%$ of species show biparental care (Cockburn 2006). However, the investments by each sex in different stages of reproduction vary and are generally higher among females (Trivers 1972). Disentangling the costs of different reproductive phases under natural conditions (i.e., without experimental manipulation of reproductive effort) represents a difficult challenge. The relative costs of egg production and mate or territory guarding can be addressed by comparing postbreeding survival of males and females in monogamous species in which partners differ in their tasks during early reproduction but share incubation and chick-rearing tasks (Tavecchia et al. 2001, Townsend and Anderson 2007). Nevertheless, in correlational studies of life-history tradeoffs, differences in quality among individuals could mask the reproductive costs (Sanz-Aguilar et al. 2008).

Long-lived seabirds of the order Procellariiformes are monogamous species with biparental care. The sexes have similar investments in incubation and chick rearing (Warham 1990, 1996). Slow reproductive rates in Procellariiformes may reflect the difficulties of feeding in pelagic environments (Lack 1968, Ricklefs
1990, Dobson and Jouventin 2007) by limiting parental effort, independent of offspring needs (Navarro and González-Solís 2007). Nevertheless, the energy invested early in the reproductive cycle may differ between sexes: females lay a single and proportionally large egg (ranging from $6 \%$ to $28 \%$ of adult body mass; Warham 1990), and males invest their energy in mate and territory guarding. If the effort invested initially in reproduction differs between sexes, sex-specific costs of reproduction would be expected, at least during a critical period such as the first breeding event (Tavecchia et al. 2001, Townsend and Anderson 2007). In fact, first-time breeders are younger and may be less efficient in general skills at feeding, reproductive tasks (e.g., coordination between partners), predator avoidance, or intraspecific competition than experienced breeders (Nur 1984, Newton 1989, Tavecchia et al. 2001, Mauck et al. 2004).

The sexually monomorphic European Storm-Petrel (Hydrobates pelagicus) is one of the smallest long-lived procellariiforms (average body mass = 28 g; Warham 1990). Differential tasks early in reproduction may lead to sex-related differences in reproductive costs: males perform courtship displays and invest in territory defense and acquisition, whereas females lay a single and proportionally large egg (25\% of adult body mass; Warham 1990). Previous studies have shown that first reproduction is costly for this species in terms of survival and breeding success (Sanz-Aguilar et al. 2008). Given the extremely large egg laid by European Storm-Petrels, we expect a higher cost of reproduction for female than for male birds, at least during a critical period such as the first breeding attempt (Tavecchia et al. 2001). On the contrary, if males compensate the female energetic investment in egg production by their specific tasks during mate or nest guarding, no differences in survival rates would be expected between sexes. Here, we analyze the potential sex-related cost of first reproduction in terms of future survival in the European Storm-Petrel. We use capture-recapture models to test differences in survival probabilities after first reproduction and subsequent breeding attempts between the sexes.

\section{Methods}

Species and study area.-We carried out our research on Benidorm Island, a 6.5-ha Special Protection Area for the conservation of the European Storm-Petrel, off the Mediterranean coast of Spain $\left(38^{\circ} 30^{\prime} \mathrm{N}, 0^{\circ} 08^{\prime}\right.$ E; Fig. 1). European Storm-Petrels breed there under boulders and in crevices on cliffs but concentrate in two caves where they nest at high densities (Mínguez 1994). Previous studies provided evidence that young individuals are highly philopatric and return to the cave where they were born (Sanz-Aguilar et al. 2008,2009 ) and that breeders have high levels of nest-site fidelity. They have an extended breeding period (incubation and the nestling periods last 40 days and 63-70 days, respectively; Mínguez 1994), eggs are rarely replaced when lost (Mínguez 1997), and offspring reach up to $130 \%$ of adult body mass 1 month before fledging (Warham 1990; Mínguez 1996, 1998). Both males and females can start breeding from 3 years of age onward (Sanz-Aguilar et al. 2009). Individuals that inhabit these colonies reproduce annually, and they rarely skip a breeding opportunity (Sanz-Aguilar et al. 2008).

Field methods.-Breeding birds have been captured by hand at their nest sites at the end of the incubation period or during the 


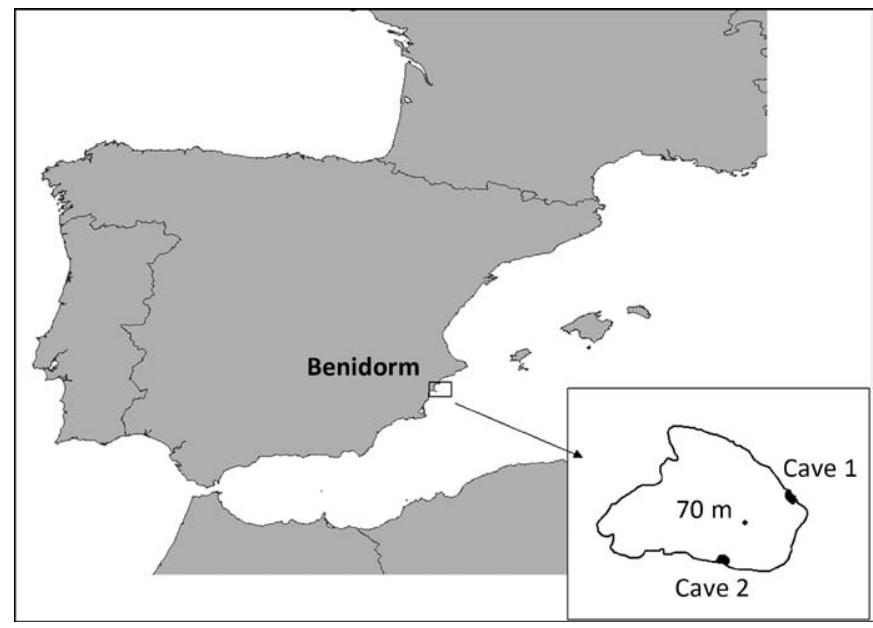

FIG. 1. Location of the study area on Benidorm Island (Alicante, Spain). The studied European Storm-Petrel colonies are located at cave 1 and cave 2 .

nestling period (i.e., during the last 2 weeks of June) since 1993 and marked with stainless steel bands with a unique alphanumeric code. To minimize nest desertion due to disturbance, breeding birds were captured only once (the first member of the pair captured was marked on the tail and head with white paint to distinguish it from its partner, to avoid recapture in the same breeding season). In addition, biometric measurements were not taken during the last years of monitoring and only the band code was noted for all birds captured, to minimize time of manipulation. Recapture effort was distributed uniformly through the colonies, and all the nests were checked for banded birds in all years. Because of high nest-site fidelity and high recapture probability (see below), birds were unlikely to be missed as a consequence of breeding dispersal. Nonbreeding individuals (i.e., prebreeders) were never captured.

During 2005-2006, most breeding individuals captured at the colonies were sexed by direct DNA examination or DNA examination of their mate (Griffiths et al. 1998). For capture-recapture analysis, we considered individual histories of known-sex birds classified at marking as first-time observed breeders during the period 2005-2010 (i.e., individuals captured for the first time in nests inspected and found empty the previous year or where two different birds were captured the previous year). We discarded first capture events of birds classified as unknown-experience breeders at marking, but we considered subsequent recaptures of these birds (i.e., experienced breeders). We also considered capture histories from 2005 to 2010 of individuals marked before 2005 (i.e., experienced breeders). Each individual first captured as a first-time observed breeder (FTOB) became an experienced breeder (EB) on the next occasion. The reverse was not possible, and individual experience should be seen as a classification with unidirectional movements between its levels (from FTOB to EB only), similar to the effect of apparent age. Consequently, we considered for analyses the individual histories of 358 known-sex individuals (176 males and 182 females) from 2005 to 2010 (1,204 captures). Of those 358 birds, 122 were captured, marked, and classified as FTOBs and 236 began their capture histories as EBs.
Capture-recapture analysis.-Survival $(\Phi)$ and recapture $(p)$ parameters were estimated simultaneously from encounter histories by maximum-likelihood estimation procedures (Choquet et al. 2009b). Models used here do not distinguish mortality from permanent emigration (out of the study sites) and, hence, survival should be considered as local (Lebreton et al. 1992). The first individual breeding attempt is equivalent to a relative age of 1 , and thereafter birds became EBs, age 2+. Consequently, for estimating survival parameters of EBs, we pooled age $2+$ of individuals classified for the first time as FTOBs and individuals classified for the first time as EBs (see details in Sanz-Aguilar et al. 2008). Because individuals rarely skip a breeding opportunity in the study colonies (Sanz-Aguilar et al. 2008), recapture probability accounts for imperfect detection of individuals present at the colonies (SanzAguilar et al. 2010, 2011).

We began model selection with a model that considered temporal variation in recapture probabilities between sexes and temporal and experience-dependent variation in survival of male and female birds and their interactions $\left(P_{\text {time.sex }}, \Phi_{\text {time.sex.experience }}\right)$. We tested the effects of annual variation and sex on recapture probability. Then, once the best-supported structure of recapture probabilities (i.e., the structure showing the lowest $\mathrm{AIC}_{\mathrm{c}}$ ) had been selected, we investigated the effects of temporal variation, sex, and breeding experience on survival probability by contrasting capture-recapture models with different sex and experience classes (Table 1).

Models were built and fit to the data using E-SURGE, version 1.8.5 (Choquet et al. 2009b). Model selection was based on Akaike's information criterion adjusted for small sample size (AIC ${ }_{c}$; Burnham and Anderson 2002). Models with an $\mathrm{AIC}_{\mathrm{c}}$ difference of $<2$ points were considered statistically equivalent (Burnham and Anderson 2002). Model averaged estimates of survival were obtained from the whole model selection using Akaike weights. The Akaike weight of a model $j, w_{i}$, represents the relative likelihood of model $j$ given the whole model selection (Burnham and Anderson 2002).

The goodness-of-fit of our general model, including two relative age classes (FTOB and EB) and two sex groups (males and females), was assessed using U-CARE, version 2.2.2 (Choquet et al. 2009a). The general model $\left(P_{\text {time.sex }}, \Phi_{\text {time.sex.experience }}\right)$ fit the data adequately $\left(\chi^{2}=28.87, \mathrm{df}=33, P=0.67\right)$.

\section{Results}

Models without a sex effect on recapture probability (models 3 and 4; Table 1) had a lower $\mathrm{AIC}_{\mathrm{c}}$ value than models that included this effect (models 1 and 2; Table 1). A model that considered temporal variation in recapture was retained as a starting point for survival analysis (model 3; Table 1 and Fig. 2). The four bestsupported models (models 7, 8, 10, and 12; Table 1) included an effect of experience on survival probabilities in some way (with grouping of males and females [model 7]; without sex effect for EB [model 8]; or without any distinction between experienced and inexperienced males [models 10 and 12]; Table 1), which shows that first-time breeders, in general, may incur survival costs of reproduction. Indeed, the sum of Akaike weights of models that included the experience effect on survival probabilities was 1 (Table 1). The sum of Akaike weights of models with a sex-related influence of experience on survival probabilities of female and male 
TABLE 1. Modeling recapture (models 1-4) and survival probability (models 3 and 5-15) of European StormPetrels at Benidorm Island. Notation: $k=$ number of estimable parameters; dev $=$ relative deviance; $\Delta \mathrm{AIC}_{\mathrm{c}}=$ the $\mathrm{AIC}_{\mathrm{c}}$ difference between the current model and the one with the lowest $\mathrm{AIC}_{\mathrm{c}}$ value; $w_{i}=\mathrm{Akaike}$ 's weight; time $=$ annual variation in the parameter considered; sex = differences between male and female birds; experience $=$ effect of individual breeding experience, including two levels (FTOB $=$ first-time observed breeder and $\mathrm{EB}=$ experienced breeder); and periods indicate interaction between effects. The model with the highest $w_{i}$ is in bold.

\begin{tabular}{lllrrrr}
\hline Model & Recapture & Survival & $k$ & dev & $\Delta$ AIC $_{c}$ & $w_{i}$ \\
\hline 1 & Sex.time & Time.sex.experience & 28 & $1,445.65$ & 11.75 & 0.00 \\
2 & Sex & Time.sex.experience & 22 & $1,458.01$ & 11.58 & 0.00 \\
3 & Time & Time.sex.experience & 24 & $1,451.74$ & 9.47 & 0.00 \\
4 & Constant & Time.sex.experience & 21 & $1,459.94$ & 11.43 & 0.00 \\
5 & Time & Sex.experience & 9 & $1,475.99$ & 2.85 & 0.08 \\
6 & Time & Sex & 7 & $1,488.29$ & 11.09 & 0.00 \\
7 & Time & Experience & 7 & $1,478.51$ & 1.31 & 0.17 \\
8 & Time & Sex.FTOB, EB (both sexes) & 8 & $1,476.50$ & 1.34 & 0.16 \\
9 & Time & Sex.EB, FTOB (both sexes) & 8 & $1,478.04$ & 2.87 & 0.08 \\
$\mathbf{1 0}$ & Time & Female FTOB, male FTOB=EB (both sexes) & 7 & $\mathbf{1 , 4 7 7 . 1 9}$ & $\mathbf{0 . 0 0}$ & $\mathbf{0 . 3 2}$ \\
11 & Time & Male FTOB, female FTOB=EB (both sexes) & 7 & $1,487.92$ & 10.72 & 0.00 \\
12 & Time & Female.experience, male (FTOB=EB) & 8 & $1,476.43$ & 1.27 & 0.17 \\
13 & Time & Male.experience, female (FTOB=EB) & 8 & $1,487.84$ & 12.67 & 0.00 \\
14 & Time & Constant & 6 & $1,488.31$ & 9.09 & 0.00 \\
\hline
\end{tabular}

birds was 0.81 (models 5, 8-10, and 12; Table 1 ) and 0.32 (models 5 and 8-9; Table 1), respectively. Model-averaged survival estimates (Table 1) showed that local survival after first reproduction of female FTOBs was 0.72 (95\% confidence interval [CI]: 0.60-0.82). Male FTOBs showed a local survival rate of 0.85 (95\% CI: 0.760.89 ). When birds became experienced, females and males showed similar local survival rates: 0.89 (95\% CI: 0.86-0.91) and 0.88 (95\% CI: 0.86-0.91), respectively.

\section{Discussion}

The first breeding attempt is a critical period during which costs of reproduction often appear (Tavecchia et al. 2001, Sanz-Aguilar et al. 2008). Our results provide unambiguous evidence that experience influences survival in European Storm-Petrels. First-time-observed female breeders had lower survival than experienced breeders of either sex, whereas first-time-observed male breeders apparently did not have lower survival than experienced breeders of either sex. The cost

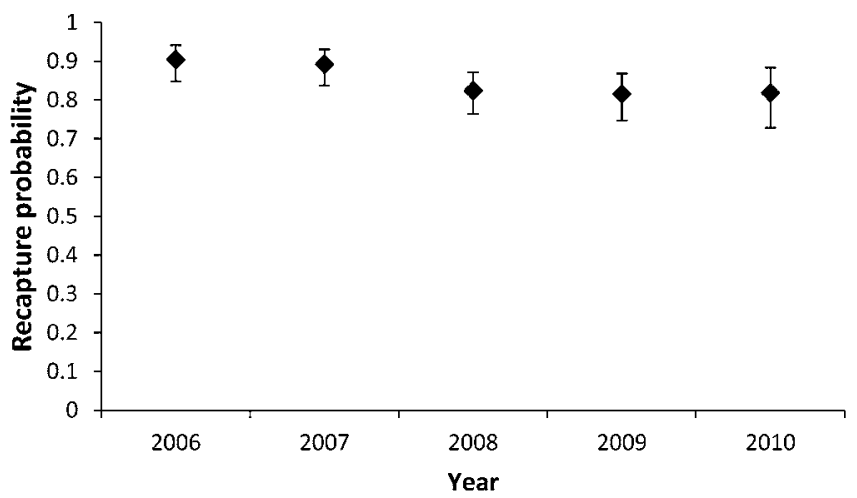

FIG. 2. Estimates of recapture probability of European Storm-Petrels studied at Benidorm Island, 2005-2010 (Table 1, model 10). of the first breeding attempt on survival and reproduction has also been reported for other long-lived bird species. For example, higher mortality rates among inexperienced than among experienced individuals have been found in White Storks (Ciconia ciconia; Nevoux et al. 2008), Greater Flamingos (Phoenicopterus roseus; Tavecchia et al. 2001), and several seabird species (Pyle et al. 1997, Barbraud and Weimerskirch 2005, Nevoux et al. 2007, Townsend and Anderson 2007). Reproductive costs, including lower performance of inexperienced individuals than of experienced ones and lower future probabilities of successful reproduction, have been detected in White Storks (Nevoux et al. 2008), Lesser Snow Geese (Chen caerulescens caerulescens; Viallefont et al. 1995), Bonelli's Eagles (Aquila faciata; Hernández-Matías et al. 2011), Black-legged Kittiwakes (Rissa tridactyla; Cam and Monnat 2000), and Antartic Fulmars (Fulmarus glacialoides; Weimerskirch 1990).

In avian reproductive systems, sex-biased mortality increases with sex biases in parental care and mating competition (Liker and Székely 2005). Among bird species, females generally expend higher levels of parental investment than males (Trivers 1972), and male-biased sex ratios at the population level are common as a consequence of higher female mortality after the breeding season (Breitwisch 1989, Liker and Székely 2005). Nevertheless, evidence of sex-specific survival costs of reproduction in monogamous species, in which both sexes invest approximately equally in parental care, is scarce (Murphy 2000, Tavecchia et al. 2001). Murphy (2000) found higher mortality in female Eastern Kingbirds (Tyrannus tyrannus) and lower future reproductive success among surviving females as a result of experimental enlargement of brood size, with no future effects for males. Tavecchia et al. (2001) found that first-time breeding female Greater Flamingos showed lower survival than equivalent males. They attributed this to the cost of egg production because male and female flamingos share incubation and chick-raising duties equally. However, Greater Flamingos are a sexually dimorphic species, in which survival differences between sexes have also been 
detected among experienced breeders. Similarly, Pyle et al. (1997) found an age- and experience-related survival cost of reproduction in both male and female Western Gulls (Larus occidentalis), but the males perform costly courtship feeding that supplements the food intake of females to reduce their costs of egg production (Ramírez et al. 2010).

The effort invested in egg production by female birds is usually measured as a function of the number and size of eggs and the number of clutches (Blackburn 1991, Nager et al. 2001, Visser and Lessells 2001). Nevertheless, reproductive effort among females may depend on their intrinsic quality (e.g., physical condition or foraging efficiency); those in better condition or with more experience produce eggs more efficiently (McNamara and Houston 1996). Several studies have shown that intrinsic traits of females, such as body condition, age, or experience, were correlated with resources allocated to egg synthesis (for review, see Christians 2002). Indeed, the first breeding event may act as a filter whereby low-quality individuals are removed by natural selection (i.e., the selection hypothesis; Forslund and Pärt 1995, Mauck et al. 2004, Sanz-Aguilar et al. 2008). According to this hypothesis, the proportion of lower-quality males would be expected to remain large in experienced individuals, and, as a consequence, a lower survival probability in experienced males than experienced females might be expected (Tavecchia et al. 2001). We found no differences in survival between experienced males and experienced females. Studies of other seabirds have suggested that males incur specific survival costs of reproduction because they invest energy and time in other activities required for reproduction, including courtship feeding before the female lays eggs, agonistic behavior in competition for mates or nests, a larger investment than their mates in time devoted to incubation and chick rearing, or a larger amount of food delivered to the young (Blackmer et al. 2005, Ramírez et al. 2010). The sexes share equally in incubation and chick-rearing tasks in European Storm-Petrels (Davis 1957). They breed underground, exhibit very high fidelity to their mate and breeding site (Sanz-Aguilar et al. 2008), and do not courtship-feed. This suggests that the effort invested in courtship and territory acquisition by male European Storm-Petrels may be low. On the other hand, it is possible that male-biased mortality of immature prospector birds may occur (e.g., by predation when prospecting for nest sites; Oro et al. 2005). In that case, the disappearance of males with the poorest antipredatory abilities or body condition may occur before first reproduction and, thus, go unrecorded.

Sex-biased local survival rates could also be a consequence of different dispersal probabilities between sexes or between birds that first begin to breed at different ages (Tavecchia et al. 2001). Age of first reproduction among procellariiform species largely overlaps between the sexes (Bradley and Wooler 1991). Sex-specific differences in natal dispersal have been explained as a means to avoid inbreeding, and female-biased dispersal in most birds is correlated with the fact that mate selection is based primarily on resource-defense breeding systems (Greenwood and Harvey 1982). Nevertheless, among many procellariiforms, intracolony dispersal (e.g., between neighboring nest sites) is more likely than intercolony dispersal (e.g., between caves or islands; Thibault 1994, Warham 1996, Genovart et al. 2007, Sanz-Aguilar et al. 2009, Gauthier et al. 2010). We have not detected statistically significant differences between the sexes in the observed age of first reproduction of known-sex individuals recruited at Benidorm Island ( $W=262.5, P=0.87$ ) or in the observed rates of nest-site dispersal during the study period $\left(\chi^{2}=3.32, \mathrm{df}=1\right.$, $P=0.07)$. Individuals rarely skip a breeding opportunity in the colonies studied (Sanz-Aguilar et al. 2008), the effect of which will be to lower recapture probabilities (Desprez et al. 2011, SanzAguilar et al. 2011). Because no differences in recapture rates have been detected between sexes, potential sex-biased probability of skipping a breeding opportunity is unlikely to have caused the observed female-biased local survival.

Egg size in storm-petrels is unusually large in relation to adult body size (Warham 1990). Our results suggest that for inexperienced female European Storm-Petrels, egg production (in addition to other costs of reproduction that are also shared with males, such as incubation and chick provisioning) may be a demanding process with negative consequences for female survival. Further research should be developed to elucidate the ultimate physiological mechanisms that generate the observed survival costs and to study the effects of such costs at the population level (e.g., population sex ratio and assortative breeding strategies).

\section{ACKNOWLEDGMENTS}

We would like to formally acknowledge the many people who participated in the field work over the years. We are indebted to the ward and Environmental Monitoring Service of Benidorm Island (Serra Gelada Natural Park-Generalitat Valenciana). G. Tavecchia, J. D. Lang, M. S. Lindberg, C. Amundson, and an anonymous reviewer made very constructive comments on the manuscript. S. García and M. Marín helped us sex the birds. A.S.A. was supported by a Marie Curie Fellowship (Ref. MATERGLOBE). The Spanish Ministry of Science funded the study through several grants (reference nos. AP2004-1128, BOS2003-01960, CGL200604325/BOS, CGL2009-08298, and SAB-2006-0014).

\section{Literature Cited}

BARBRAUd, C., AND H. WEIMERSKIRCH. 2005. Environmental conditions and breeding experience affect costs of reproduction in Blue Petrels. Ecology 86:682-692.

Blackburn, T. M. 1991. An interspecific relationship between egg size and clutch size in birds. Auk 108:973-977.

Blackmer, A. L., R. A. Mauck, J. T. Ackerman, C. E. Huntington, G. A. Nevitt, and J. B. Williams. 2005. Exploring individual quality: Basal metabolic rate and reproductive performance in storm-petrels. Behavioral Ecology 16:906-913.

Bradley, J. S., and R. D. Wooller. 1991. Philopatry and age of first-breeding in long-lived birds. Pages 1657-1665 in Proceedings 20th International Ornithological Congress (B. D. Bell, Ed.). Congressional Trust Board, Wellington, New Zealand.

BREITWISCH, R. 1989. Mortality patterns, sex ratios, and parental investment in monogamous birds. Pages 1-50 in Current Ornithology, vol. 6 (D. M. Power, Ed.). Plenum Press, New York.

Burnham, K. P., And D. R. Anderson. 2002. Model Selection and Multimodel Inference: A Practical Information-Theoretic Approach, 2nd ed. Springer-Verlag, New York. 
CAM, E., AND J.-Y. Monnat. 2000. Apparent inferiority of first-time breeders in the kittiwake: The role of heterogeneity among age classes. Journal of Animal Ecology 69:380-394.

Choquet, R., J.-D. Lebreton, O. Gimenez, A. M. Reboulet, And R. PRADEL. 2009a. U-CARE: Utilities for performing goodness of fit tests and manipulating CApture-REcapture data. Ecography 32:1071-1074.

Choquet, R., L. Rouan, and R. Pradel. 2009b. Program E-SURGE: A software application for fitting multievent models. Pages 845-865 in Modeling Demographic Processes in Marked Populations (D. L. Thomson, E. G. Cooch, and M. J. Conroy, Eds.). Springer, New York.

Christians, J. K. 2002. Avian egg size: Variation within species and inflexibility within individuals. Biological Reviews 77:1-26.

Clutton-Brock, T. H., S. D. Albon, and F. E. Guinness. 1985. Parental investment and sex differences in juvenile mortality in birds and mammals. Nature 313:131-133.

Cockburn, A. 2006. Prevalence of different modes of parental care in birds. Proceedings of the Royal Society of London, Series B 273:1375-1383.

DAVIS, P. 1957. The breeding of the storm petrel. British Birds 50:371-383.

de Heij, M. E., P. J. van den Hout, and J. M. Tinbergen. 2006. Fitness cost of incubation in Great Tits (Parus major) is related to clutch size. Proceedings of the Royal Society of London, Series B 273:2353-2361.

Desprez, M., R. Pradel, E. Cam, J.-Y. Monnat, and O. Gimenez. 2011. Now you see him, now you don't: Experience, not age, is related to reproduction in kittiwakes. Proceedings of the Royal Society of London, Series B 278:3060-3066.

Dobson, F. S., AND P. Jouventin. 2007. How slow breeding can be selected in seabirds: Testing Lack's hypothesis. Proceedings of the Royal Society of London, Series B 274:275-279.

Drent, R. H., AND S. DAan. 1980. The prudent parent: Energetic adjustments in avian breeding. Ardea 68:225-252.

Forslund, P., AND T. PÄRT. 1995. Age and reproduction in birdsHypotheses and tests. Trends in Ecology \& Evolution 10:374-378.

Gauthier, G., E. Milot, and H. Weimerskirch. 2010. Smallscale dispersal and survival in a long-lived seabird, the Wandering Albatross. Journal of Animal Ecology 79:879-887.

Genovart, M., D. Oro, J. Juste, and G. Bertorelle. 2007. What genetics tell us about the conservation of the critically endangered Balearic Shearwater? Biological Conservation 137:283-293.

Greenwood, P. J., AND P. H. Harvey. 1982. The natal and breeding dispersal of birds. Annual Review of Ecology and Systematics 13:1-21.

Griffiths, R., M. C. Double, K. Orr, and R. J. G. Dawson. 1998. A DNA test to sex most birds. Molecular Ecology 7:1071-1076.

Hanssen, S. A., D. Hasselquist, I. Folstad, and K. E. Erikstad. 2005. Cost of reproduction in a long-lived bird: Incubation effort reduces immune function and future reproduction. Proceedings of the Royal Society of London, Series B 272:1039-1046.

Harshman, L. G., AND A. J. Zera. 2007. The cost of reproduction: The devil in the details. Trends in Ecology \& Evolution 22:80-86.

Hernández-Matías, A., J. Real, R. Pradel, A. Ravayrol, And N. Vincent-Martin. 2011. Effects of age, territoriality and breeding on survival of Bonelli's Eagle Aquila fasciata. Ibis 153:846-857.
LACK, D. 1947. The significance of clutch-size. Ibis 89:302-352.

LACK, D. 1968. Ecological Adaptations for Breeding in Birds. Methuen, London.

Langston, N. E., S. Freeman, S. Rohwer, and D. Gori. 1990. The evolution of female body size in Red-winged Blackbirds: The effects of timing of breeding, social competition, and reproductive energetics. Evolution 44:1764-1779.

Lebreton, J.-D., K. P. Burnham, J. Clobert, and D. R. AnderSON. 1992. Modeling survival and testing biological hypotheses using marked animals: A unified approach with case studies. Ecological Monographs 62:67-118.

LiKer, A., AND T. SzÉKELY. 2005. Mortality costs of sexual selection and parental care in natural populations of birds. Evolution 59:890-897.

Mauck, R. A., C. E. Huntington, and T. C. Grubb, JR. 2004. Age-specific reproductive success: Evidence for the selection hypothesis. Evolution 58:880-885.

McNamara, J. M., And A. I. Houston. 1996. State-dependent life histories. Nature 380:215-221.

Mínguez, E. 1994. Censo, cronología de puesta y éxito reproductor del Paíño Común (Hydrobates pelagicus) en la Isla de Benidorm (Alicante E de España). Ardeola 41:3-11.

Mínguez, E. 1996. Nestling feeding strategy of the British stormpetrel Hydrobates pelagicus in a Mediterranean colony. Journal of Zoology (London) 239:633-643.

Mínguez, E. 1997. Evidence of occasional re-laying in the British storm-petrel (Hydrobates pelagicus). Colonial Waterbirds 20:102-104.

Mínguez, E. 1998. The costs of incubation in the British stormpetrel: An experimental study in a single-egg layer. Journal of Avian Biology 29:183-189.

Monaghan, P., And R. G. Nager. 1997. Why don't birds lay more eggs? Trends in Ecology \& Evolution 12:270-274.

Murphy, M. T. 2000. Evolution of clutch size in the Eastern Kingbird: Tests of alternative hypotheses. Ecological Monographs 70:1-20.

Nager, R. G. 2006. The challenges of making eggs. Ardea 94:323-346.

Nager, R. G., P. Monaghan, and D. C. Houston. 2001. The cost of egg production: Increased egg production reduces future fitness in gulls. Journal of Avian Biology 32:159-166.

NAVARro, J., AND J. GonZÁLEZ-Solís. 2007. Experimental increase of flying costs in a pelagic seabird: Effects on foraging strategies, nutritional state and chick condition. Oecologia 151:150-160.

Nevoux, M., J.-C. Barbraud, And C. Barbraud. 2008. Breeding experience and demographic response to environmental variability in the White Stork. Condor 110:55-62.

Nevoux, M., H. Weimerskirch, and C. Barbraud. 2007. Environmental variation and experience-related differences in the demography of the long-lived Black-browed Albatross. Journal of Animal Ecology 76:159-167.

Newton, I., Ed. 1989. Lifetime Reproduction in Birds. Academic Press, London.

Nur, N. 1984. Increased reproductive success with age in the California Gull: Due to increased effort or improvement of skill? Oikos 43:407-408.

Oro, D., A. DE León, E. Mínguez, And R. W. Furness. 2005. Estimating predation on breeding European Storm-Petrels (Hydrobates pelagicus) by Yellow-legged Gulls (Larus michahellis). Journal of Zoology (London) 265:421-429. 
Pyle, P., N. Nur, W. J. Sydeman, and S. D. Emslie. 1997. Cost of reproduction and the evolution of deferred breeding in the Western Gull. Behavioral Ecology 8:140-147.

Ramírez, F., K. A. Hobson, O. S. Wangensteen, M. Genovart, G. Viscor, C. SAnpera, And L. Jover. 2010. A physiological marker for quantifying differential reproductive investment between the sexes in Yellow-legged Gulls (Larus michahellis). Journal of Experimental Marine Biology and Ecology 396:48-52.

REZniCK, D. 1992. Measuring the costs of reproduction. Trends in Ecology \& Evolution 7:42-45.

RickLEFS, R. E. 1990. Seabird life histories and the marine environment: Some speculations. Colonial Waterbirds 13:1-6.

Sanz-Aguilar, A., B. Massa, F. Lo Valvo, D. Oro, E. Mínguez, AND G. TAVECCHIA. 2009. Contrasting age-specific recruitment and survival at different spatial scales: A case study with the European Storm-Petrel. Ecography 32:637-646.

Sanz-Aguilar, A., G. Tavecchia, M. Genovart, J. M. Igual, D. Oro, L. Rouan, AND R. Pradel. 2011. Studying the reproductive skipping behavior in long-lived birds by adding nest-inspection to individual-based data. Ecological Applications 21:555-564.

Sanz-Aguilar, A., G. Tavecchia, E. Mínguez, B. Massa, F. Lo Valvo, G. A. Ballesteros, G. G. Barberá, J. F. Amengual, A. Rodríguez, M. MCMinn, AND D. Oro. 2010. Recapture processes and biological inference in monitoring burrow-nesting seabirds. Journal of Ornithology 151:133-146.

Sanz-Aguilar, A., G. Tavecchia, R. Pradel, E. Mínguez, AND D. ORo. 2008. The cost of reproduction and experiencedependent vital rates in a small petrel. Ecology 89:3195-3203.

Stearns, S. C. 1992. The Evolution of Life Histories. Oxford University Press, Oxford, United Kingdom.

Tavecchia, G., R. Pradel, V. Boy, A. R. Johnson, and F. Cézilly. 2001. Sex- and age-related variation in survival and cost of first reproduction in Greater Flamingos. Ecology 82:165-174.
Thibault, J.-C. 1994. Nest-site tenacity and mate fidelity in relation to breeding success in Cory's Shearwater Calonectris diomedea. Bird Study 41:25-28.

Townsend, H. M., AND D. J. Anderson. 2007. Assessment of costs of reproduction in a pelagic seabird using multistate mark-recapture models. Evolution 61:1956-1968.

Trivers, R. L. 1972. Parental investment and sexual selection. Pages 136-179 in Sexual Selection and the Descent of Man 1871-1971 (B. Campbell, Ed.). Aldine, Chicago, Illinois.

Viallefont, A., F. Cooke, And J.-D. Lebreton. 1995. Age-specific costs of first-time breeding. Auk 112:67-76.

VISSER, M. E., AND C. M. LeSSELls. 2001. The costs of egg production and incubation in Great Tits (Parus major). Proceedings of the Royal Society of London, Series B 268:1271-1277.

Wagner, E. C., C. A. Stables, and T. D. Williams. 2008. Hematological changes associated with egg production: Direct evidence for changes in erythropoiesis but a lack of resource dependence? Journal of Experimental Biology 211:2960-2968.

Warham, J. 1990. The Petrels: Their Ecology and Breeding Systems. Academic Press, London.

Warham, J. 1996. The Behaviour, Population Biology and Physiology of the Petrels. Academic Press, London.

WeimerskirCh, H. 1990. The influence of age and experience on breeding performance of the Antarctic Fulmar, Fulmarus glacialoides. Journal of Animal Ecology 59:867-875.

Williams, T. D. 2005. Mechanisms underlying the costs of egg production. BioScience 55:39-48.

Zera, A. J., And L. G. Harshman. 2001. The physiology of life history trade-offs in animals. Annual Review of Ecology and Systematics 32:95-126.

Associate Editor: M. S. Lindberg 